\title{
Ingmar Bergman's Guests at the Last Supper in the Time of Nuclear Threats
}

\author{
Jan Dlask
}

\begin{abstract}
This article discusses the film Nattvardsgästerna (1963) - released in the U.S. as Winter Light, and in the U.K. as The Communicants - in the context of the Swedish post-war religious scene and Ingmar Bergman's other productions of the period. The film is read theologically with an assumption that the author carries on a certain religious dialogue, whatever its form may be. With the basis of the film in the title, it asks about the meaning of the Lord's Supper celebration and of the individual 'guests', i.e. the film's main characters: Tomas Ericsson, Märta Lundberg and Jonas Persson. The article applies a comparative perspective to the relevant texts of the Old and (especially) New Testaments and includes pericopes and verses concerning the doubting Thomas, the biblical Martha and the prophet Jonah.
\end{abstract}

\section{Keywords}

Ingmar Bergman, Swedish film, Winter Light/The Communicants, theological reading of movie, the doubting Thomas

This article is published as an output of the Charles University (Faculty of Arts) research programme Progres Q12: Literature and Performativity. 
Ingmar Bergman's film Nattvardsgästerna (1963) (literally 'guests at the last supper'; American title Winter Light, British title The Communicants) has given rise to many discussions concerning its central theme: religion. In March 1963, Variety wrote: 'an extremely moving and fascinating film for the religiously aware, and a somewhat boring one for the religiously indifferent' (20). The most thorough discussion of the film outside of Sweden took place in Italy and the U.S. Cinema Nuovo saw it as a paradoxical film about atheism played out in a religious setting (R. Renzi, no. 163), and discussed the crisis of the main pastor character, Tomas Ericsson, in terms of the Protestant emphasis on individual salvation rather than on symbolic congregational rites (G. Oldrini, no. 166). American press reception of the film was rather negative; e.g. The New Yorker dismissed the film as the latest installment of Bergman's running debate with God (STEENE 2005: 256-257).

In Sweden, religious implications of the film were debated both in church publications and traditional newspapers. Bergman, as well as theologians (e.g. ministers of the Swedish Lutheran State Church), took part in the polemics. A Göteborg bishop commented on Nattvardsgästerna as a deeply degrading document on the church. Dagens Nyheter referred to Bergman as a 'religiously infected' person, oscillating between faith and doubt (M. Edström), and to S. E. Olsson the pastor's role depicted a psychological transference of the concept of God from father-fixation to mother-dependence (Scen och salong 48, no. 4). Theologian and Lutheran pastor Hans Nystedt interpreted the film as a religious parable with Märta Lundberg, the schoolteacher, portrayed as a Christ figure, both in Svenska Dagbladet (1963) and later in his book Ingmar Bergman och kristen tro [Bergman and Christian faith], published in 1989 and comprising personal interpretations in pursuit of biblical allusions in several Bergman's films (STEENE 2005: 256-257, 907; cf. NYSTEDT 1989: 30-37). Bergman's filmmaking has been approached from the religious point of view also in many other studies (see STEENE 2005: 256-257, 905-908).

According to the Czech film scholar Jiří Cieslar ${ }^{1}$ (referring to Bergman's own expression): the film is a milestone in Bergman's work, one with which he excluded the religious aspect from his existence (CIESLAR 1982: 408-409). Also, the film theoretician Ivo Pondělíček ${ }^{2}$ states that in this film Bergman gets rid of the religious elements and parts with a religiousness as a vision of today's needs of human beings. In the film, only a conception of the basic questions of human existence, not dominant features in a religious sence, can be found, and the religiousness is visible only in the form of symbolic motifs (PONDĚLÍČEK 1967: 60, 72, 139, 142, 154).

In the introduction, this article briefly describes the Swedish religious scene at the time when the film was made and presents the film in the context of Bergman's preceding production. Subsequently, in terms of religion it uses a perspective which is opposite to that of Cieslar and Pondělíček, and, on the contrary, assumes the existence

1 Jiří Cieslar (1951-2006) was a Czech film and literary critic and university lecturer, a professor of film studies at the Faculty of Arts of the Charles University in Prague.

2 Ivo Pondělíček (* 1928), a Czech film theorist and psychologist, later also a sexologist and painter. He taught film psychology at two universities in Prague. Author of a monograph on Bergman - see (PONDĚLÍČEK 1967 [Bergman's philosophical film and the problems of its interpretation). 
of dominant religious features in the film in the form of a dialogue with religion, whatever its character may be - even a subversive one. With a basis in the film title (Nattvardsgästerna), it asks about the meaning of the Lord's Supper celebration in the film and about the meaning of its individual characters, the guests, especially the main characters of Tomas Ericsson, Märta Lundberg and Jonas Persson - but in another way than Nystedt (see above): both of these meanings are referred to the relevant texts and names of Old and New Testaments, the latter in particular.

\section{The 1950s and the Swedish spiritual scene. Ingmar Bergman's reaction}

As the Swedish literary historian Göran Hägg formulates, the processes that took place on the Swedish spiritual scene in the 1950s can be characterized as 'the removal of the metaphysical motivations of morality', 'avskaffandet av moralens metafysiska motiveringar' (HÄGG 2005: 131). Svenska kyrkan, The Church of Sweden, an Evangelical Lutheran national church in this country, then still a state church and even nowadays in Sweden percieved as universalistic, as well as its favoured traditional values definitely lose their influence on society and citizens. As a result of scandals that shook it from inside, it paradoxically started to be considered harmless as an institution forestalling a genuine alternative religiousness. Even a certain kind of indiference to its own dogmas began to be manifested within the church itself. The church was, on the one hand, accepted as an institution providing 'social services' particularly in the field of education, serving worships during the negotiations at the state level or during military exercises, providing baptisms, confirmations, marriages and funerals even for implicit atheists, and especially leading parish registers, important for the system of state social tax payments and allowances (HÄGG 2005: 128-130).

On the other hand, the ruling political establishment was largely anti-Church, if not openly atheistic. That establishment especially comprised representatives of the labor movement, in Sweden traditionally led by the social democracy. In a parliamentary way it forces the Church to act in manners that are not in accordance with its beliefs: it is compelled to wed divorced people or to baptize children of nonbelievers. Even the permission to appoint woman priests is basically forced on the Church by the government and the parliamentary majority. However, Svenska kyrkan subordinates, which Hägg interprets as an effort to preserve its power and economic position (HÄGG 2005: 128-130).

Against this background, Ingmar Bergman started his filmmaking. His early movies Sommaren med Monika (1953; Summer with Monika) and Sommarnattens leende (1955; Smiles of a Summer Night) were in this time interpreted as a presentation of 'den svenska omoralen' and 'den svenska synden' (HÄGG 2005: 132), 'Swedish immorality and sin', connected with the foreshadowed situation and atmosphere, referring, for example, to scenes with nude bodies, hints of sexual intercourse and other erotic motifs, which occurred in them. In addition to these films, Bergman focuses on religious themes and goes into a personal religious dialogue. 'The Silence of God' (see also below) can be found in Det sjunde inseglet (1956; The Seventh Seal), set in the Middle Ages. Also, in 
Jungfrukällan (1959; The Virgin Spring), God did not make Himself known and allows the rape of a young girl and her father's subsequent revenge to the guilty culprits. Smultronstället (1957; Wild Strawberries) includes an absurd scene in which the existence of God should be decided in the brawl of two boys (HÄGG 2005: 132-133). According to Cieslar (see above), in the above-mentioned films from 1956 and 1957 Bergman still grows an idea of a silent but still anticipated God, by incorporating purely earthly, moral content into it and by identifying him with love.

However, the message of Bergman's film from 1963 is supposed to be, as mentioned above, different.

\title{
Worship in Mittsund
}

The story takes place in a small Swedish village of Bergman's contemporary time named Mittsund, in which a medieval church is situated.

\begin{abstract}
Klockan är tolv på dagen en söndag $i$ slutet av november. Det skymmer över slätten och blåsten kommer med rå fukt från myrmarken österut. (...) Det har just börjat snöa, glest men envist, marken är frusen sedan länge, snart täcks vägar och åkrar av en gråvit hinna.
\end{abstract}

[It is twelve o'clock at noon one Sunday in late November. It is cloudy over the plains, and the wind is coming with the raw moisture from the marshland in the east. (...) It has just begun snowing, thinly but persistently, the ground has been frozen for a long time, the roads and fields will be soon covered by a gray-white coating.] (BERGMAN 1963/1973: 70)

A worship with the Lord's Supper is just being celebrated by the local pastor, Tomas Ericsson. There are three hundred and sixty-seven parishioners living in the village, a number exceeding the number of days in a calendar year by two or one. However, only nine people, the communicants, are attending the worship, aside from the organist and his wife in the organ loft. Together with the priest, there are twelve people at the worship service, just as many as those with whom Jesus ate his last supper.

Tomas reads the provision of communion:

Vår Herre Jesus Kristus, i den natt då han blev förrådd, tog ett bröd, tackade Gud, bröt det och gav åt lärjungarna och sade: Tagen och äten. Detta är min lekamen som varder utgiven för eder. Gören detta till min åminnelse. (...) Sammanlunda tog han ock kalken, tackade Gud och gav åt lärjungarna och sade: Dricken härav alla. Denna kalk är det nya förbundet i mitt blod, som varder utgjutet för många, till syndernas förlåtelse. Så ofta I dricken den, så gören detta till min åminnelse.

[The Lord Jesus, on the night he was betrayed, took bread, and when he had given thanks, he broke it and said, 'This is my body, which is for you; do this in remembrance of me'. (...) 
In the same way, after supper he took the cup, saying, 'This cup is the new covenant in my blood; do this, whenever you drink it, in remembrance of me.' (1 Corinthians 11:23-25, cf. also Matthew 26:26-29; Mark 14:22-25; Luke 22:14-20; John 6:51-58).] (BERGMAN 1963/1973: 72-73)

Nevertheless, only five parishioners go to Tomas to receive Communion in remembrance of Jesus: the local teacher Märta Lundberg, fisherman Jonas Persson and his wife, the churchwarden Algot Frövik and an old woman from Hol. They are going to become the main characters in the film.

\section{Communion}

The so-called provision of Communion, the Lord's Supper or the Eucharist, the main part of the service, reflects an event from the end of Jesus' life. Eating with his twelve disciples, Jesus already knew his life was in immediate danger, and he told them how he aimed to deal with his death. He connected his fate with the proclaimed kingdom of God. The provision is related in several ways to his teaching and lifelong attitudes.

The Czech evangelical theologian Petr Pokorný (1997: 54) reflects this relation in several levels:

1. The Synoptic Gospels, Matthew, Mark, and Luke identify this event with the day when the Passover of the Israelites was commemorated by eating of the lamb. It is, therefore, at least in the concept of these three Evangelists, a transformation of this celebration.

2. The fact that everyone, unlike during paschal feasts or other festive occasions, drank from one chalice, that Jesus had let go round, means that his death will be good for all who dine with him and also for all the other people (cf. Mark 10:45: For even the Son of Man did not come to be served, but to serve, and to give his life as a ransom for many.')

3. The celebration of this feast by Christians after Easter is one of the main manifestations of the belief that God has not forsaken Jesus and through him opens the way to the goal of life and history.

4. The teachings about the elements of bread and wine that are transformed into the Body and Blood of Christ towards participants of dining express the certainty that similar dinings, when they are held as a conscious reminder of his last supper, reveal the effects of his life and his sacrifice.

5. All previous dinings, in the light of renewed dinings conducted after Easter with Christ, gain weight as precursors of the renowned community of people of different origin, generations, and nations, and as precursors of a vanishing point of human lives and history. The community united by the relationship to God is what will go over from this age into eternity. The Book of Acts of the Apostles presents a picture 
of the early Christian celebrations of the Lord's Supper, showing their significance for the emerging church (cf. Acts 2:41-42).

\section{Tomas Ericsson}

The priest's first name, Tomas, can be understood as a reference to Thomas, one of the Twelve Apostles, Jesus' disciples. He is for example mentioned in the pericope Jesus Appoints the Twelve of the Gospel According to Mark:

These are the twelve he appointed: Simon (to whom he gave the name Peter), James son of Zebedee and his brother John (to them he gave the name Boanerges, which means 'sons of thunder'), Andrew, Philip, Bartholomew, Matthew, Thomas (underlined by the author), James son of Alphaeus, Thaddaeus, Simon the Zealot and Judas Iscariot, who betrayed him. (Mark 3:16-19; cf. also Matthew 10:2-4, Luke 6:13-16, Acts 1:13)

His character is described thoroughly especially in the Gospel According to John. When the apostles hesitate to return to Judea, where the Jews tried to stone Jesus, Thomas says: 'Let us also go, that we may die with him.' (John 11:16). In John 14:5, Jesus speaks about the way to the place where he is going, His Father's house, that is prepared also for the apostles. Thomas says to him, Lord, we don't know where you are going, so how can we know the way?' And finally, in John 20:19-24, Jesus, risen from the dead, appears to His disciples, Thomas just not being with them.

So, the other disciples told him, 'We have seen the Lord!' But he said to them, 'Unless I see the nail marks in his hands and put my finger where the nails were, and put my hand into his side, I will not believe.' A week later his disciples were in the house again, and Thomas was with them. Though the doors were locked, Jesus came and stood among them and said, 'Peace be with you!' Then he said to Thomas, 'Put your finger here; see my hands. Reach out your hand and put it into my side. Stop doubting and believe.' Thomas said to him, 'My Lord and my God!' Then Jesus told him, 'Because you have seen me, you have believed; blessed are those who have not seen and yet have believed' (John 20:25-29).

'Doubting' Thomas is at first skeptical when he does not see Jesus with his own eyes. It is only after Jesus appears also to him that he shows his belief. The following is a discussion of the way that Tomas Ericsson is Bergman's version of the biblical Thomas.

Tomas, currently celebrating the worship, is suffering from flu and severe fever. His physical illness could be seen as a spiritual disease. After the worship service, we witness his conversation with one of the participants, a local teacher named Märta Lundberg. She is the closest person to him. Her overwhealming feeling for the pastor is love, but it is one-sided: Tomas does not feel the same. At first, Tomas trys to satisfy Märta with a fictitious reason for continually refusing to take her as his wife: the good reputation of a priest. However, the real reason is, as Märta will recognize, something 
else: Tomas does not love her. The conversation on their relationship and its not too optimistic perspectives ends with Märtha's statement that Tomas should learn to love, not to die of self-loathing.

The pastor Tomas is a widower: his wife (twenty years younger than he) had died of a serious illness several years before. According to his own words, he loved his wife very much, and when she died, he died as well, and he does not care whether his life goes on and what will happen to him. He tells Märta directly that his wife was everything to him - something Märta can never be, although she is trying to do her best.

In the course of Märta's and Tomas's conversation (and the following action), it turns out that the bleak state of Tomas's soul is not only caused by the tragic passing of his wife and by the fact that his relationship with Märta has no prospects. In Cieslar's interpretation, the profound connection of faith with ability to love is relevant here - if Tomas has lost one, he also lost the other, both faith and love (1982: 409). The definitive picture of the spiritual state of Tomas's mind is revealed at the moment when another parishioner, Jonas Persson, worrying about the state of the world, comes to a kind of personal confession to the pastor after the liturgy. Tomas starts gradually to agree that threatening news that distress Jonas are really unbearable, the links are so annihilating, and God is so distant, and in the sense of helplessness Tomas understands Jonas.

The roles are reversed: Jonas becomes even more unsure and frightened when Tomas confesses to him, admitting by himself the need of Jonas's help. In a theological monologue, he confides that he had become a priest because of the want of his parents, who had protected him from all evil, odiousness, danger, cruelty, and wickedness of the world. His god was absurd, a totally private paternal god, loving people, and most of all Tomas self, and therefore Tomas harbours feelings of indifference to the gospel message and a jealous resentment to Christ - it is a god whom he put into his mind by himself, compiled from a variety of in every possible way collected pieces, a god who guarantees all imaginable safety from the fear of death and life and who willingly gives desired answers to all possible questions.

Tomas, however, understood the true state of affairs upon the Spanish Civil War when he served as a chaplain in the Navy in Lisbon. He realized he did not want to see (and understand) the fact that he was living with his own god in his own world. He had arranged this world by himself so that nothing could disturb him - just as Jonas lives with his own fear. Tomas thus reflects that he, a withdrawn, spoiled and fearful poor wretch, had become a bad priest. God, when confronted with the reality, changed into something hideous, abominable, a spiderlike monster.

Bergman's priest Tomas thus shares doubts with the New Testament doubting Thomas, but unlike the biblical figure, he does not finally believe in God, for God does not appear to him. 


\section{Märta Lundberg}

The abovementioned verse John 11:16, in which Thomas calls on the other apostles to go to die for Jesus, is immediately followed by the pericope 'Jesus Comforts the Sisters of Lazarus'. On his arrival to Bethany, Jesus finds that the dead Lazarus, Martha's and Mary's brother, has already been in the tomb for four days. Jesus comes to comfort both sisters in the loss of their brother and says to Martha that her brother will rise again (cf. John 11:17-37). In the subsequent pericope, Jesus raises Lazarus from the dead (John 11:38-44). The following chapter of the gospel starts with the pericope 'Jesus Anointed at Bethany' (John 12:1-10), where a dinner is given in Jesus' honor, and Martha serves.

This role of hers is even more relevant in Luke 10:38-42, a pericope called 'At the Home of Martha and Mary':

As Jesus and his disciples were on their way, he came to a village where a woman named Martha opened her home to him. She had a sister called Mary, who sat at the Lord's feet listening to what he said. But Martha was distracted by all the preparations that had to be made. She came to him and asked, 'Lord, don't you care that my sister has left me to do the work by myself? Tell her to help me!' 'Martha, Martha,' the Lord answered, 'you are worried and upset about many things, but few things are needed-or indeed only one. Mary has chosen what is better, and it will not be taken away from her.' (Luke 10:38-42)

Because of her exemplary care, Martha is often referred to as an attentive housekeeper. But Martha, unlike her sister Mary, who is sitting at Jesus's feet and is listening to his word, has only a great deal of business upon her head and hands, when serving Jesus, and she complains about Mary. Although both sisters sincerely believe in Jesus, Martha, the owner of the house, forgets the 'only one needed thing' for her host's duties. (Cf. NOVOTNÝ 1956: 402, 404).

Tomas's sentence 'Jag är trött på dina omsorger, ...' (I'm tired of your care!) (BERGMAN 1963/1973: 107)), directed towards Märta Lundberg, is Bergman's variation on Jesus's words: 'Martha, Martha, (...), you are worried and upset about many things, ...' (Luke 10:41). Martha's namesake in Bergman's film, Märta, is also not given the Gift of Listening; cf. Tomas: 'Vill du höra på mig ett ögonblick. / Märta: Förlåt! Jag pratar hela tiden!' (Tomas: Would you listen to me for a moment? / Märta: Sorry! I talk all the time!) (BERGMAN 1963/1973: 106). Judging by her letter to Tomas, her behavior has also characteristics of childishness, as she tries to explore God's power through the method of trial and error: she asks Tomas, who allegedly believes in the effect of intercessory prayer, to pray for the disappearance of eczema on her hands.

According to Pondělíček (1967: 48), Märta's role is to give safety and love. She tries to care for Tomas as much as possible. She has been thus expressing her great concern for Tomas's both private and work life for a long time. She believes that Tomas will not be able to make do without her in the future. She is one of the five communicants who came to the Lord's Supper and received Communion, for she interprets it as 
a feast of love, that she has felt for several years for the pastor. Though, she did it with a wry smile: on the contrary to the biblical Martha, she is as much of an unbeliever as Tomas.

\section{Jonas}

Jonas (also Jonah) is an Old Testament prophet of the northern kingdom of Israel. Because of his anabasis to the people of Nineveh, which he apparently thought to have been useless, he occupied himself by thoughts to end his life. He was confronted with a parable, provided directly by the Lord (see the pericope of 'Jonah's Anger at the Lord's Compassion' in Jonah 4: 1-11; cf. also Luke 11, 30-32; 2 Kings 14, 25).

Bergman's Jonah, Jonas Persson, lives in the post-WWII era. A significant phenomenon of the period is the fear of a global nuclear war. Jonas suffers from an obsessive fear of political development in China. The Chinese are, reportedly, brought up to hate and wage war, and it is only a matter of time until they develop an atomic bomb. First Tomas recommends Jonas to rely on God, to stand up to the disaster, not to wait for it with hands folded and to give the forces of peace to all the support, but later he gives up his consolation and, on the contrary, opens his own heart to Jonas (see above). In the latter part of the film, the message, that Jonas has just carried his suicidal thoughts through, is brought by an old woman from Hol, who also received Communion as one of the abovementioned five.

Bergman's Jonas is (in contrast to the biblical Jonas) not addressed by the Lord, and commits suicide for his fear of something indefinite, with which he cannot cope mentally, as well as Judas Iscariot, one of Jesus's disciples, who kills himself filled with remorse after betraying Jesus (Matthew 27: 3-10; Acts 1: 16-20). In this sense, it should be pointed out, that the name Jonas, in the Bible reserved only to the prophet, is after the sound similar to Judas, at least in Swedish, Bergman's mother tongue. Bergman's Jonas is a fisherman by occupation, which is possible to relate to this verse: 'Come, follow me,' Jesus said, 'and I will send you out to fish for people.' (Matthew 4:19). In Swedish is this parallel even more visible, when the word is presented as a substantive (Jag ska göra er till människofiskare - I will make you fishers of men).

\section{The Silence of God}

Doubting Tomas thus remains doubting. Märta is worried and upset about many things as in the Bible - but in contrast to Mary's sister, she is not a believer. The third apostle gives up fishing for people and commits suicide. These motifs are even emphasized by several scenes, in which Bergman does not leave his audience in doubt about his own doubts about God's existence. In front of the altar picture of Christ, hanging on the cross between God the Father's knees, Tomas says to himself, 'This ridiculous picture!' The pastor mentions precisely the words 'the silence of God' (see above) and confesses 
that he was wide of God during the service. After Jonas's departure, in the total silence of the vicarage, Tomas realizes the silence of God again, and moans Christ-like 'My God, my God, why have you forsaken me?' (Matthew 27:46; Mark 15:34; cf. also Psalm 22:1). But when he finds that God no longer exists, he feels ultimately free. Another parallel to the motif of calling to God occurs once again in Tomas's childhood memory: he had woken up frightened in an empty house in the evening, climbed out of bed and looked for his father in all rooms and then out on the river bank: he cried, yelled, but no one answered.

The motif of abandonment by God, respectively the silence of God is once again emphasized at the very end. Tomas and Märta arrive together at the neighboring village of Frostnäs, where the pastor should be celebrating another service. The churchwarden Algot Frövik and the church organist Fredrik Blom, both who had been present during the service in Mittsund, are also involved in the preparation of the worship in Frostnäs. In a dialogue, led by Tomas and Algot, the churchwarden, referring to his bodily pains, first plays down the four-hour suffering of Jesus on the cross. Then, however, he tackles a reflection, that Jesus's mental suffering must have been even much worse at the moment when all the disciples had forsaken him, and he was left alone. He learned, that no one understood, and especially a few minutes before he died, he had fallen into a terrible uncertainty whether everything he had preached was not a lie.

No single parishioner had arrived at the church in Frostnäs, only Märta Lundberg is sitting on the bench. The worship will be thus served only for her.

\section{Conclusion}

Bergman's apostles are characters fluctuating in doubt between faith and unfaith, or in cruel psychic tortures, longing to possess each other and considering themselves superior to the others. They are hypocritical, speculating and self-deceptive, they slander each other - as pointed out by Jiří Cieslar when he states: 'nalézaji se v jakémsi bezbranném odkryti a projevuji bolestnou neschopnost orientovat se ve vlastním nitru a ve vztazich $k$ druhým' ['they are in a kind of a defenseless exposure and show a painful inability to orient themselves in their own inner world and in their relations with others'].

The interpretation of Bergman's film could follow a line of a new transformation - if not directly an abolition - of the Lord's Supper celebration (see point 1) in a completely contradictory sense: the death of God is no longer good to all mankind (point 2), the belief, that God has not forsaken Jesus, does not exist anymore (point 3 ), and there can be no talk about revealing of the effects of Jesus' life and sacrifice (point 4). Even Bergman's community of believers that is supposed to be formed by the Lord's Supper (point 5) is woeful: in Mittsund it consists of five apostles instead of twelve, in Frostnäs there is only one person present in the service, fewer than '... two or three...' (cf. Matthew 18:20: '...For where two or three gather in my name, there am I with them.') 
The traditional religious faith is in the time that was in the beginning characterized as religiously skeptical and indifferent, paradoxically questioned by references to its central canonized texts. This by no means implicates Bergman's lack of interest in religious questions, but it is possible to talk about the rejection of what Bergman understands under the term 'traditional faith'. His dialogue can be, as several times pointed out above, viewed as really subversial: unlike the biblical figures, neither his Thomas, a priest, nor his Martha are believers, and his Jonas, on the contrary to the biblical one, does commit suicide, similarly as Judas, the betrayer.

The interpretation of Tomas's monologue directed towards Jonas, which is the central 'confession of unfaith' of the film, would from the theological point of view also be possible in the opposite direction. Tomas rejects a private God, put into his mind by Tomas himself, with whom he lived in his own world, who loved Tomas most of all people, and who protected Tomas from the confrontation with the unpleasant reality of the world.

Is this just the very God that makes Himself known, for example, in the New Testament Gospels?

The Czech editor, literary reviewer and translator Martin Machovec, when confronting the work of the poet, prose writer and philosopher Egon Bondy with the present, reminds the words of the theologian Tomáš Halík:

Co se muselo stát s křestanstvím, když Ludwig Feuerbach, zakladatel humanistického ateismu, mohl vidět křestanského Boha jako Velkého bratra z Orwellova románu, jako konkurenta svobody, pravdy a skutečnosti člověka? [...] Německá teoložka Dorothee Sölle správně poukazuje na to, že za častými otázkami »Kde byl Bůh v Osvětimi« či »Proč Bůh nezabrání válkám«, je právě tento falešný, hluboce nekřestanský pojem mocného boha, zbavujícího nás naší vlastní odpovědnosti. V tomto smyslu můžeme my křestané být hluboce vděčni ateistům typu Feuerbacha, Nietzscheho, Freuda či Marxe, že za nás odmítli a rozbili tohoto bůžka, tuto karikaturu křestanského boha, stvořenou projekcí lidských přání a strachů.

[What happened to Christianity, when Ludwig Feuerbach, the founder of humanistic atheism, could see the Christian God as Big Brother in George Orwell's novel as a competitor of freedom, truth, and reality of man? [...] The German theologian Dorothee Sölle points rightly out, that it is this false, deeply unchristian notion of a mighty god, freeing us of our own responsibility, that is behind the frequently asked questions 'Where was God in Auschwitz' or 'Why does not God prevent wars.' In this sense, we Christians can be deeply grateful to the atheists Feuerbach, Nietzsche, Freud and Marx, who instead of us refused and broke this idol, this caricature of the Christian God, created by the projection of human desires and fears.] (UOAA, JAR 2010: 3)

As one of these 'atheists', Machovec also assigns a philosopher, writer and poet Egon Bondy, a personality of the Czech underground, whose work allegedly shows the liberating future as open, necessarily dark or apocalyptic. It is also possible to annex Ingmar Bergman to them: his Tomas rejects the God, who protects him from reflecting the reality of the Spanish Civil War. 


\section{Bibliography}

BERGMAN, Ingmar. 1963/1973. Såsom i en spegel. Nattvardsgästerna. Tystnaden. Stockholm: PAN/ Norstedt, 1963/1973.

CIESLAR, Jiří. 1982. Mlčení, šepoty a výkřiky Ingmara Bergmana. In Ingmar Bergman. Filmové povídky. Praha: Odeon, nakladatelství krásné literatury a umění, n.p., 1982: 400-416.

HÄGG, Göran. 2005. Välfärdsåren. Svensk historia 1945-1986. Stockholm: Månpocket, 2005.

NOVOTNÝ, Adolf. 1956. Biblický slownik. Dil 1. A - R. Praha: Kalich, Ústřední církevní nakladatelství, 1956.

NYSTEDT, Hans. 1989. Ingmar Bergman och kristen tro. Stockholm: Verbum, 1989.

POKORNÝ, Petr. 1997. Nový zákon. In Miloš Bič and Petr Pokorný. Co neviŕs o Bibli. Úvod do studia Starého a Nového zákona. Praha: Česká biblická společnost, 1997: 131-170.

PONDĚLÍČEK, Ivo. 1967. Bergmanưv filosofický film a problémy jeho interpretace. Praha: Filmový ústav, 1967.

STEENE, Birgitta. 2005. Ingmar Bergman: A Reference Guide. Amsterdam: Amsterdam University Press, 2005.

UOAA, JAR. 2010. Jedna otázka pro Martina Machovce. Tuar, literárni obtýdenik XXI: 17 (21. 10. 2010): 3 .

All biblical quotations according to New International Version (NIV). Available online at <https://www.biblica.com/bible/niv/>

\section{Mgr. Jan Dlask, Ph.D.}

Finnish Studies, Department of Germanic Studies

Faculty of Arts, Charles University in Prague,

Nám. Jana Palacha 1/2, 11638 Prague 1, Czech Republic

jan.dlask@ff.cuni.cz

Jan Dlask is a Senior Lecturer in Finnish Literature. He studied Finnish and Swedish and specialised in Finland-Swedish literature. Wrote his doctoral thesis on Tikkanen-Kihlman debate (its abridgement in Swedish in Historiska och litteraturhistoriska studier 87, ed. by SLS i Finland). During 2014-2016 concerned with the Czech Science Foundation post-doc project 'Dějiny finskošvédské literatury v perspektivě bourdieuovské sociologie' (The History of Finland-Swedish Literature through the Perspective of Bourdieusian Sociology); a monograph in Czech published in 2018. Other research interests: literary sociology (P. Bourdieu), Finnish literature in the Czech literary scene, popular literature (noir reception), reviews of Finnish literature. For more information see http://fin.ff.cuni.cz/cs/ustavkatedra/jan-dlask/. 
